\title{
Turizm Bölümü Öğrencilerinin Girişimcilik Eğilimlerini Etkileyen Demografik Faktörler : İki Devlet Üniversitesi Karşılaştırması
}

\author{
Gülsevim Yumuk Günay ${ }^{\mathrm{a}}$
}

\begin{abstract}
Öz: Girişimcilik son dönemin en önemli konularından birisidir. Çünkü birçok ülke girişimcilik sayesinde ekonomik anlamda gelişme ve kalkınmayı gerçekleştireceklerinin farkındadırlar. Bu nedenle ülkelerinde girişimcilik potansiyelini ortaya çıkaracak ve onları destekleyecek maddi ve manevi fırsatlar yaratma yoluna gitmektedirler. Türkiye'nin de turizm sektöründe girişimcilere ihtiyacı vardır. Türkiye'nin gerek turistik destinasyon zenginliği gerekse sektörün emek yoğunluğu sebebiyle turizm bölümü öğrencilerini girişimciliğe yönlendirmek istemesi önemlidir. Bu çalışmada Trakya Üniversitesi ve Afyon Kocatepe Üniversitesi Turizm bölümü öğrencilerinin girişimcilik eğilimleri karşılaştırılarak benzerlikler ve farklılıklar ortaya konulmuştur. Bu amaçla çalışmanın güvenilirliğini test etmek için Cronbach Alpha, demografik faktörlerin öğrencilerin girişimcilik eğilimlerine etkisini test etmek için ise Kruskal Wallis analizi uygulanmıştır. Çalışmada iki üniversite öğrencilerinin eğilimlerini etkileyen demografik faktörler arasındaki benzerlikler daha çok aynı yaş gruplarında ve aynı hedefler(kendi işini kurma, kamu kuruluşunda çalışmayı düşünmeme) yönünde iken farklılıklar cinsiyette ve sınıflarda (dönemlerde) görülmüştür. Çalışmanın önemli bulgularından birisi de Trakya Üniversitesindeki öğrencilerin almış oldukları girişimcilik eğitiminin girişimcilik eğilimlerini kısmen ve kısa süreliğine etkilemesidir.
\end{abstract}

Anahtar Sözcükler: Girişimci, Girişimcilik, Girişimcilik Eğilimi

JEL Sınıflandırması: M16, M53

\section{Demographic Factors that affect the Entreprenuership Intentions of Students in Tourism Department: Comparison of Two State Universities}

\begin{abstract}
Recently, entreprenuership is one of the most important subjects. Because most countries are aware that they can achieve economic development and growth by the help of entreprenuership. Therefore, these countries try to create tangible and intangible opportunities that would unfold entreprenuership potential. Turkey needs entreprenuers in tourism sector. It is important for Turkey to lead their students who studies in tourism department to entreprenuership because of abundance in touristic destinations and labor-intensive characteristics of the tourism sector. In this study, entreprenuership intentions of students in tourism departments at Afyon Kocatepe University and Trakya University are compared, and similarities and differences in students' entreprenuership intentions are put forth. For this purpose, Cronbach Alpha is used to test the reliability of the study, and Kruskal Wallis analysis is conducted to test the impact of demographic factors on the entreprenuership intentions of students. The similarities of demographic factors that affect the students' entreprenuership intentions of both universities are seen on the same age groups and same objectives (establishing their own businesses, not considering to work in state agencies), and differences are observed in terms of gender and grades (semester). One of the important findings of the study is that entreprenuership education at Trakya University affected the entreprenuership intentions of the students partially and for a short period of time.
\end{abstract}

Keywords: Entrepreneur, Entrepreneurship, Entrepreneurship Intention

JEL Classification: M16, M53

\footnotetext{
${ }^{a}$ Assist.Prof. Dr., Trakya University, School of Applied Sciences, Edirne, Turkiye, gulsevimyumuk@gmail.com
} 


\section{Giriş}

1700 'lü yıllarda ortaya çıkan girişimcilik kavramı ile ilgili ilk çalışmalar ekonomi alanında gerçekleşmiştir. Dolayısıyla Fransız iktisatçı J.B. Say tarafından klasik üretim faktörleri arasında sayılan emek, sermaye ve doğa faktörlerinin yanına dördüncü bir üretim faktörü olarak ilave edilmiştir (Bozkurt ve Erdurur, 2013: 58). Girişimcilik, karşılığında parasal ve kişisel tatmin ödülü alınan, gerekli zaman ve çabayı harcayarak ve finansal, sosyal ve psikolojik riskleri göze alarak yeni bir şeyler üretme sürecidir (Coulter, 2001: 4). Girişimcilik insan iradesinin bir sonucu olarak ortaya çıkan ve bireylerin geçmiş bilgi birikimlerine göre oluşturdukları gönüllü davranışların neticesinde meydana gelen bir davranış biçimidir (Minniti ve Bygrave, 2000:25). Bu davranışı sergileyen girişimci ise yeni fikirler oluşturan, bunları uygulamaya dönüştüren ve bütün bunları yaparken yaratıcılı̆ını ortaya koyup, istek ve şevkini kullanan kişidir (Kao, 1989:91). Girişimci tanımı; işletme sahipliği, liderlik etme, karar verme, şirket yönetiminde aktif olma gibi birçok fonksiyonu içine almaktadır (Brandstätter, 1997:160).

Bir işi kurmak ve onu devam ettirmek çok kolay olmamaktadır. Dolayısıyla girişimcilerde bunu başaracak cesaret, yetenek ve yaratııılığın bir arada bulunması gerekmektedir. Bu durum ancak söz konusu faktörleri bünyesinde barındıran girişimciler sayesinde mümkün olabilmektedir (Bozkurt ve Erdurur, 2013: 59). Bireyi girişimciliğe yönelten aile, eğitim, kişisel değerler, yaş, rol modelleri, toplum, iş tecrübesi vb. (Chen ve Lai, 2010:10; Hisrich ve Peters, 2002) farklı faktörler söz konusudur. Girişimciliği şekillendiren bu faktörler içsel ve dışsal olmak üzere ikiye ayrılmaktadır. Kişinin kendi ayakları üzerinde durma isteği, masa başı işlerin kendine uygun olmadığını düşünmesi veya kişilik olarak başkalarının emri altında çalışamaması içsel faktörlerden bazılarıdır (Korkmaz, 2000:165, Özdemir ve Mazgal, 2012:92). Kültür ve eğitim ise çevresel faktörlerin içinde yer almakta olup dışsal faktörlerin önemli unsurlarından birisidir (Yumuk Günay, 2013:98). Bu çalışmada, girişimcilik eğilimlerini etkileyen beş temel faktör iki farklı üniversite öğrencileri karşılaştırılarak araştırılmaya çalışılmıştır.

\section{Girişimci ve Girişimcilik Kavramları}

Girişimci; emek, sermaye ve doğal kaynaklar olarak belirtilen üretim faktörlerini, başkalarının ihtiyacını karşılayacak mal ve hizmetler üretmek üzere tedarik eden ve uygun şekilde birleştiren kişidir. Girişimci, bir üretim faktörü olup genellikle kar etme ana amacı ile hareket eder ve riske de katlanır (Mucuk, 1993: 18). Girişimci kavramı içinde genel olarak doğan fırsatlardan yararlanma, yeni fırsatlar yaratabilme ve risk alma özellikleri aranmaktadır. (Erdoğan, 2008:5). Joseph Schumpeter girişimci için "yeniliği sunan birey" demektedir (Deakins, 1999: 11). Girişimci fırsatı görüp bu fırsatın ekseninde bir organizasyon oluşturabilme kabiliyetine sahip kişidir (Bygrave ve Hofer,1991:13,21). Hebert ve Link (1988:47) ise girişimciyi malların, kaynakların veya kurumların kullanımını, biçimini ve konumunu etkileyen yargısal kararlar verme sorumluluğunu almada uzmanlaşmış kişiler olarak tanımlamaktadır.

Girişimci olmayı etkileyen üç önemli faktörden bahsedebiliriz. Bunlar; demografik faktörler, sosyal faktörler ve psikolojik faktörlerdir. Demografik faktörler; bireylerin cinsiyeti, eğitimi, yaşı, iş tecrübesi, girişimci bir aile çevresinden gelmesi, ailenin ilk çocuğu olması, medeni durumu, sosyoekonomik statüsü, ailenin eğitim/gelir durumu, kardeş sayısı gibi özelliklerdir (Kayış, 2010: 23). Sosyal faktörler; çocukluk, aile ortamı, akrabalar ve arkadaşlardır. Son olarak psikolojik faktörler ise; kişisel niteliklerimiz bizim kim olduğumuzu, hangi psikolojik ve sosyal pozisyonda bulunduğumuzu önemli ölçüde açıklamaya çalışan unsurlardır (Aytaç, 2006: 142).

Girişimcilik ise, yeterli emek ve zaman ayırarak, mali, fiziksel ve sosyal riskleri göze alarak, parasal ödüller, kişisel tatmin ve bağımsızlık elde ederek yeni bir değer yaratma süreci olarak görülmektedir (Hisrich ve Peters, 2002: 47). Girişimcilik sürekli değişen dinamik bir durumdur (Chicken, 2002: 41). Girişimciliğin bu dinamik özelliği nedeniyle farklı yazarlar farklı bakış açıları ortaya koymuşlardır. Örneğin Schumpeter girişimsel faaliyetlerin dengeli bir sistem olarak kabul ettiği piyasanın denge durumunu bozan bir süreç olarak görürken (Sciascia ve De Vita, 2004: 6), Philipsen (1998:4)'da ekonomide dengesizlik yaratan merkezi bir girişimsel aktivite olarak tanımlamaktadır. Kirzner ise Schumpeter'in aksine girişimciyi dengesizlik avantajını elde eden dengeleyici bir aktör olarak düşünmüş (Sciascia ve De Vita, 2004: 9) ve girişimsel piyasa 
sürecinin sistematik açıdan dengeyi sağlama eğilimini yansıttığını iddia etmiş̧ir (Adaman ve Devine, 2002: 336-337). Ekonomik açıdan farklı yazarların farklı bakış açıları söz konusu olsa da işletmecilik açısından tüm yazarların birleştiği nokta, bir fırsatı fark etme ve o fırsatı kullanabilmek için bir organizasyon oluşturma faaliyeti olduğudur (Mueller ve Thomas 2000: 52). Aslında Audretsch (2003:2) girişimciliğin bir anlayış ve davranış biçimi olduğunu belirterek son noktayı koymuştur.

\section{3. Üniversite Öğrencilerinin Girişimcilik Eğilimlerinin Belirlenmesine Yönelik Çalışmalar}

Koh (1996)'un Hong Kong'daki 100 lisansüstü öğrenci üzerinde yaptığı çalışmada; öğrencilerin girişimci kişilik özellikleri (başarma ihtiyacı, kontrol odağı, risk alma eğilimi, belirsizliğe tolerans, kendine güven ve yenilikçilik) belirlenmeye çalışımıştır. Çalışmanın sonucunda, risk alma eğilimi, belirsizliğe tolerans ve yenilikçilik özelliklerinin girişimci eğilime sahip olan öğrencilerde, sahip olmayan öğrencilere göre daha fazla olduğu ortaya çıkmıştır.

Wang ve Wong (2004), Singapur'daki üniversite öğrencilerinin girişimcilik eğilimlerini ortaya çıkarmayı amaçlayan bir çalışma gerçekleştirmişlerdir. Çalışmalarının sonucunda; cinsiyet, ailenin girişimci olması ve eğitim düzeyi girişimciliği etkileyen faktörler olarak ortaya konurken, girişimci ailenin gelir durumu ve etnik kökenin girişimcilik üzerinde etkili olmadığı anlaşılmıştır.

Gürol ve Atsan (2006), “Üniversite öğrencileri arasındaki Girişimcilik Özellikleri: Türkiye'deki Girişimcilik Eğitim ve Öğretimi Konusundaki Bazı Sezgiler" isimli çalışmalarında iyi girişimciler yetiştirmek için girişimcilik özelliklerinin geliştirilmesi ile ilgili girişimcilik eğitimi konusunda bakış açısı sağlamaya çalışmışlardır. Türkiye'deki iki üniversiteyi (Yıldız teknik Üniversitesi ve Akdeniz Üniversitesi) kapsayan bu çalışmada, girişimcilik eğilimine sahip olan öğrencilerin olmayanlara göre belirsizlik toleransı ve özgüven hariç diğer girişimcilik özelliklerinin (yenilik, başarı ihtiyacı, kontrol odağı ve risk alma) yüksek olduğunu ortaya koymuşlardır. Ayrıca öğrencilerin girişimcilik özelliklerinin geliştirilmesine yönelik Türkiye'deki yükseköğretimdeki eğitim programlarında takım çalışması ve işletme oyunları gibi beceri geliştirici yöntemlere yer verilmesi gerektiği önerilerinde bulunmuşlardır.

Cansız (2007)'ın çalışması, üniversite öğrencilerinin girişimcilik özelliklerinin belirlenmesini amaçlamaktadır. Bu kapsamda "girişimcilik için gerekli kişisel niteliklerin belirlenmesi", "girişimcilerin başarısını etkileyen faktörlerin belirlenmesi" ve "potansiyel girişimcilerin yaratıcılık, risk alma eğilimi ve kontrol odaklılı̆ı ile ilgili özelliklerinin belirlenmesi" gibi alt amaçlar belirlenmiştir. Çalışma, öğrencilerinin potansiyel birer girişimci olabileceklerini ortaya koyarken yönlendirme eksikliği nedeniyle bunu gerçekleştiremediklerini ortaya çıkarmıştır. Ayrıca kız ve erkek öğrencilerin girişimcilik özelliklerin ölçen sorulara verdikleri yanıtlar açısından, kız öğrencilerin sezgisel anlamda, erkek öğrencilerin ise maddi kazanç odaklı olarak girişimciliğe eğilimlerinin olduğu da gözlemlenmiştir.

Türker ve Sönmez Selçuk (2009), “Hangi Faktörler Üniversite Öğrencilerinin Girişimcilik Eğilimleridir? isimli çalışmalarında Türkiye'deki 300 üniversite öğrencisinin girişimcilik eğilimine etki eden bağlamsal faktörlerden eğitim, ilişkiler ve yapısal desteğin etkilerini araştırmışlardır. Çalışmada, öğrencilerin girişimcilik eğiliminde yapısal destek ve eğitimin etkisinin olduğunu ortaya koymuşlardır.

Akın ve Zor (2009) çalışmalarında, işletme eğitiminin girişimcilik yetenekleri üzerindeki etkisini altı kamu ve üç vakıf üniversitesi olmak üzere toplam dokuz üniversitedeki 394 adet dördüncü sınıf öğrencisi üzerinde incelemişlerdir. Araştırma sonucunda, işletmecilik eğitim programlarının girişimcilik niteliklerini geliştirdiği yönünde algıların varlığı tespit edilmiştir. Ayrıca, çalışmanın diğer önemli bir sonucu da kamu üniversitelerine oranla, vakıf üniversitesindeki öğrencilerin girişimcilik (bağımsız iş yapma ve çalışma teşebbüsünde bulunma) eğilimlerinin daha fazla olduğu yönündedir.

Chen ve Lai (2010)'nin Taiwan'daki teknik kolej öğrencileri ve üniversitedeki işletme bölümü öğrencileri üzerinde yaptıkları araştırmada, kişilik özellikleri bağımlı, girişimciliğe yönelik tutumu bağımsız ve çevresel bilişimi (girişimcilik eğitimiyle verilen girişimcilik bilgileri) müdahale değişken olarak ele alınarak incelemişlerdir. 792 öğrenci üzerinde yapılan bu çalışmada, girişimcilik eğitiminin ve girişimci kişilik özelliklerinin öğrencilerin girişimcilik eğilimlerini teşvik ettiği ortaya konulmuştur (Chen ve Lai, 2010:10). 
İşcan ve Kaygın (2011), Kafkas Üniversitesi ile Kırıkkale Üniversitesi i.i.i.B.F.'nin son sınıf öğrencilerine yönelik çalışmalarında, öğrencilerin karşılaştırmalı olarak girişimcilik eğilimlerini belirlemeye çalışmışlardır. Çalışmada Kafkas Üniversitesi öğrencilerinin kendine güven, yenilik, başarma ihtiyacı, kontrol odağına sahip olma ve risk alma konularında Kırıkkale üniversitesi öğrencilerine göre anlamlı derecede daha başarılı oldukları, ancak belirsizliğe karşı toleranslarının düşük olduğu ortaya konulmuştur. Kafkas üniversitesi öğrencilerinin cinsiyetleri bakımından bir fark gözlenmezken, Kırıkkale'de okuyan öğrencilerde erkek öğrencilerin belirsizliğe tolerans gösterme konusunda bayan öğrencilerden anlamlı derecede daha başarılı oldukları gözlemlenmiştir.

Güreş̧i (2014) çalışmasında, üniversitede okuyan öğrencilerin almış oldukları eğitimle mesleki eğilimlerinin sağlanabileceği düşüncesinden hareketle, "girişimcilik" dersi alan Atatürk Üniversitesi İspir Hamza Polat MYO Büro Yönetimi ve Sekreterlik Bölümü öğrencilerinin girişimcilik eğilimini ölçmeye çalışmıştır. Çalışmada öğrencilerin birçoğunun fakülteye devam etmeyi istemesinin yanında ailelerinin ekonomik (orta gelirli) ve sosyal (memur-iş̧̧i-çiftçi) statüleri gereği, bir an önce hayata tutunmak istedikleri anlaşılmaktadır. Öğrencilerin çoğunluğunun (\%60.97) kendilerini girişimci olarak tanımladığı, özellikle bu öğrencilerin girişimcilik eğiliminin ve kendilerine olan güvenin diğer öğrencilere göre yüksek olduğu anlaşılmıştır. Her öğrencinin potansiyel girişimci olduğu çalışmanın diğer önemli bulgusudur.

Karasakal ve Aksu (2014), Meslek Yüksekokullarının teknik ve sosyal programlarında okuyan öğrencilerin program farklılığının, onların kişisel özgüven oluşturmada ve beraberinde girişimci kişilik eğilimlerinin oluşmasında bir etkisinin olup olmadığını "Sosyal karşılaştırma ölçeği" kullanarak ortaya koymaya çalışmışlardır. Çalışmada öğrencilerin büyük bir çoğunluğunun program karşılaştırması yapmadan girişimci kişilik özellikleri taşıdıkları görülmüştür. Program karşılaştırması yapıldığında ise teknik program öğrencileri kendilerini daha yetersiz hissetmektedir. Sosyal programda okuyanlar ile öğrencilerin genelinde 20 yaş üstünde, erkek ve ikinci öğretimde okuyan öğrencilerin girişimci kişilik eğilimleri olumlu yönde daha anlamlı çıkmıştır.

Karimi, Biemans, Lans, Chizari ve Mulder (2016) "Girişimcilik Eğitiminin Etkisi: İranlı Öğrencilerin girişimcilik eğilimleri ve Fırsatçı kimlikleri üzerine bir araştırma" isimli çalışmada zorunlu ve seçmeli girişimcilik derslerinin etkilerini 205 öğrenci üzerinde test edilmiştir. Çalışma sonunda seçmeli girişimcilik dersinin önemli ölçüde öğrencilerin girişimcilik eğilimlerini arttırdığı, bu artışın zorunlu girişimcilik dersinde görülmediği anlaşılmıştır.

Entrialgo ve Iglesias (2016) "Girişimcilik Eğiliminin Öncüllerinden Girişimcilik Eğitiminin Aracı Rolü” başlıklı çalışmada, girişimcilik eğitimi ile girişimciliğe yönelik algı, sübjektif normlar, algılanan davranış kontrolü ve girişimcilik eğilimleri arasında nasıl bir etkileşimin olduğunu test etmeyi amaçlamışlardır. 338 son sınıf lisans öğrencileri üzerinde yapılan çalışmada yapısal eşitlik modeli analizi kullanılmıştır. Sonuçlar girişimcilik eğitiminin sübjektif normlar ve algılanan davranış kontrolü arasında önemli bir aracılığa sahip olduğu, girişimcilik eğilimi ile sübjektif normlar arasında güçlendirici bir ilişki sağladığı yönündedir.

\section{Araştırma}

\subsection{Araştırmanın Amacı}

Öğrencilerin girişimcilik eğilimini etkileyen demografik özellikler literatürde aile, rol modeli, eğitim, yaş ve cinsiyet olarak açıklanmaktadır(Hisrich ve Peters, 1995:55-58; Kutaniş vd., 2006:390-391). Dolayısıyla çalışmada bu demografik faktörler ele alınarak, aile ve rol modelini temsilen "baba mesleği", eğitimi temsilen öğrencilerin bulundukları "sınıf-dönem", yaş, cinsiyet ve hayallerini temsilen de "mesleki hedef" ele alınmıştır. Çalışma sadece demografik faktörlere (cinsiyet, yaş, sınıf (dönem), baba mesleği ve mesleki hedef) odaklanmış olması açısından önemlidir. Diğer taraftan turizm sektörü birçok ülke için önemlidir bu bağlamda potansiyel girişimci adayı olarak görülen turizm bölümü öğrencilerinin girişimcilik eğilimlerinin demografik faktörler ele alınarak iki farkı üniversite karşılaştırılarak ortaya konulması açısından araştırmaya değer görülmektedir. Bu farklılı̆̆ın belirlenmesinin öğrencileri girişimciliğe sevk edecek diğer çalışmalar da yaş, cinsiyet, baba mesleği vb. faktörlerin üzerinde durulması ve bu yönlü çalışmalar yapılması açısından önemlidir. 


\subsection{Araştırmanın Metodolojisi}

Çalışmada, kolayda örnekleme yöntemiyle ulaşabileceğimiz öğrenci sayısı göz önüne alınarak Trakya Üniversitesi ve Afyon Kocatepe Üniversitesi turizm bölümü öğrencileri tercih edilmiştir. Bu iki üniversitenin gelişmişlik düzeyleri, kapsamları, öğrenci özellikleri açısından karşılaştırma yapılmasına uygun olduğu düşünülmüştür. Diğer taraftan "Girişimcilik" dersinin Trakya Üniversitesi'ndeki turizm bölümü öğrencilerinin müfredatında var iken Afyon Kocatepe Üniversitesi müfredatında olmaması da iki üniversitenin turizm öğrencilerinin girişimcilik eğilimlerinin karşılaştırılmasında eğitimin vurgulanması açısından önemli olabilir.

Anket formu iki kısımdan oluşmaktadır. Birinci kısım öğrencilere ait demografik özellikleri, ikinci kısım ise öğrencilerin girişimcilik eğilimlerini ölçmek için Girginer ve Uçkan (2004) ile Balaban ve Özdemir (2008:139)'in çalışmalarında kullandığı 5'li likert ölçeği ile hazırlanan 14 ifadeden (EK:1) oluşmaktadır. Veriler tüm öğrencilerle gerçekleştirilen yüzyüze görüşme/anket tekniği ile elde edilmiştir. Çalışmaya gönüllü olarak katılan öğrencilerden 642 adet anket elde edilmiş ancak 14 adet anket eksiklikler nedeniyle çalışma dışı bırakıımıştır. Dolayısıyla çalışmada 628 adet öğrenci anketi kullanılmıştır. Veriler SPSS programı ile değerlendirilmiş olup verilerin normal dağılıma sahip olup olmadığını görmek için Kolgomorov-Smirnov, verilerin güvenilirliği için Cronbach Alpha, demografik faktörler ile girişimcilik eğilimleri arasındaki ilişkiyi test etmek için Kruskal Wallis analizi uygulanmıştır.

\subsection{Araştırmaya Ait Demografik Özellikler}

Çalışmada üzerinde durulacak girişimcilik eğilimini etkileyen faktörlere ait frekans ve yüzde değerleri "demografik özellikler" tablosunda detaylı bir şekilde verilmiştir.

Tablo 1. Demografik Özellikler

\begin{tabular}{|c|c|c|c|c|c|c|c|}
\hline & & Frekans & $\%$ & & & Frekans & $\%$ \\
\hline \multirow{2}{*}{ Cinsiyet } & Kadın & 309 & 49,2 & \multirow{6}{*}{ Sinıf } & Hazırlık & 158 & 25,2 \\
\hline & Erkek & 319 & 50,8 & & 1.Sinif & 241 & 38,4 \\
\hline \multirow{2}{*}{ Eğitim } & Ön Lisans & 148 & 23,6 & & 2.Sinıf & 117 & 18,6 \\
\hline & Lisans & 480 & 76,4 & & 3.Sinif & 74 & 11,8 \\
\hline \multirow{5}{*}{ Baba Mesleği } & Kamu Çalışanı & 85 & 13,5 & & 4.Sinıf & 3 & 0,5 \\
\hline & $\begin{array}{l}\text { Özel Sektör } \\
\text { Çalışanı }\end{array}$ & 100 & 16,0 & & $2+$ veya $4+$ & 35 & 5,6 \\
\hline & $\begin{array}{l}\text { Serbest } \\
\text { Meslek (işvr.) }\end{array}$ & 114 & 18,1 & \multirow{7}{*}{ Yaş } & 18 ve $18^{\prime}$ den az & 26 & 4,0 \\
\hline & Emekli & 226 & 36,0 & & 19 & 81 & 12,9 \\
\hline & Diğer & 103 & 16,4 & & 20 & 123 & 19,6 \\
\hline \multirow{6}{*}{ Mesleki Hedef } & $\begin{array}{l}\text { Devlet } \\
\text { Memurluğu }\end{array}$ & 181 & 28,8 & & 21 & 146 & 23,2 \\
\hline & $\begin{array}{l}\text { Baba } \\
\text { mesl.sürd. }\end{array}$ & 12 & 1,9 & & 22 & 105 & 16,7 \\
\hline & Özel Sektör & 199 & 31,7 & & 23 & 76 & 12,1 \\
\hline & $\begin{array}{l}\text { Kendi İşini } \\
\text { Kurma }\end{array}$ & 193 & 30,7 & & 24 ve $24+$ & 71 & 11,2 \\
\hline & Diğer & 43 & 6,9 & \multirow{2}{*}{$\begin{array}{l}\text { Öğrenci } \\
\text { Sayısı }\end{array}$} & Trakya Üniversite & 340 & 54 \\
\hline & & & & & Afyon Üniversite & 288 & 46 \\
\hline
\end{tabular}

Araştırmaya; katılan öğrencilerin \%54'ü Trakya Üniversitesi, \%46’sı Afyon Kocatepe Üniversitesi öğrencilerinden oluşmaktadır. Çalışmaya "cinsiyet" açısından \%50,2 erkek ve \%49,2 kadın katılımcı katkı sağlamıştır. Söz konusu katılımcıların \%76,4'ü lisans, \% 23,6'sı önlisans mezunudur. "Baba mesleği" faktöründe \% 36'sının babası emekli, \%18,1'inin babası serbest meslek (işveren) çalışanı, \%16'sı özel sektör çalışanıdır. Öğrencilerin \%25,2'si hazırlık, 38,4'ü 1.Sınıf (2.dönem), \%18,6'sı 2.Sınıf(4.dönem), \%11,8'i 
3.Sınıf(6.dönem), \%0,5'i 4.Sınıf(8.dönem), \%5,6'sı okulu uzayan yani $2+$ (4.dönem+)ve 4+(8.dönem+) konumundaki öğrencilerden oluşmaktadır. Yaş gruplarının frekanslarına bakıldığında öğrencilerin \%23,2'si 21 yaşında, \%19,6'sının 20 yaşında, \%16,7'sinin 22 yaşında, \%12,9'unun 19 yaşında, \%12,1'inin 23 yaşında ve toplam olarak \%11,2 oranında da 24 ve 24 yaşın üzerinde görülmektedir. Mesleki hedefleri açısından ise, \% 31,7 özel sektör, \%30,7 ile kendi işini kurma, \%28,8 ile devlet memurluğu yer almaktadır.

\subsection{Bulgular}

Çalışmada Trakya Üniversitesi ile Afyon Kocatepe Üniversitesi öğrencilerinin girişimcilik eğilimleri her bir demografik faktör ayrı ayrı ele alınarak değerlendirilmiş ve sonuçlar aşağıdaki tablolarda verilmiştir.

\subsubsection{Cinsiyet}

Bu çalışmada da ilk olarak cinsiyet faktörü ele alınmış ve cinsiyet açısından önce tüm öğrenciler (Trakya ve Afyon Kocatepe üniversitesi) ile girişimcilik eğilimleri arasındaki ilişki (normal dağılım olmadığı ve varyanslar eşit dağılmadığı için) Kruskal Wallis analizi ile test edilmiştir. Tablo 2'de p değeri kabul edilebilir olan ve farklılıklar bulunan eğilimlerin frekansları ve ortalama değerleri verilmiştir. Ondört girişimcilik eğilimi arasından üç eğilim ile ilgili anlamlı bir ayrışma olduğu bulunmuştur. Bu eğilimlerden Eğilim A (Turizm bölümü mezunları, kendi işlerini kurmak için gerekli fırsatları yaratma yeteneğine sahiptirler)'da kadınların daha fazla girişimciliğe eğilimi görülürken Eğilim F (Bir işin fırsatlar sunması; emniyetli ve garantili olmasından daha önemlidir) ve Eğilim J (Gerçekleri zorlayarak sezgiye, hislere ve hayallere dayalı hareket etmeyi tercih ederim)'de ise erkeklerin girişimcilik eğiliminin daha fazla olduğu anlaşılıışır.

Tablo 2. Cinsiyet ve Girişimcilik Eğilimleri (Trakya Üniversitesi ve Afyon Kocatepe Üniversitesi)

\begin{tabular}{|l|c|c|c|c|}
\hline $\begin{array}{l}\text { GENEL } \\
\text { Cinsiyet }\end{array}$ & $\mathbf{P}$ & & Frekans & $\begin{array}{c}\text { Ortalama } \\
\text { Değer }\end{array}$ \\
\hline Ĕilim A & 0.022 & & & \\
\hline & & Kadın & 306 & 328,08 \\
\hline & & Erkek & 317 & 296,48 \\
\hline Eğilim F & 0.031 & & & \\
\hline & & Kadın & 306 & 295,23 \\
\hline & & Erkek & 317 & 325,38 \\
\hline Eğilim J & 0.005 & & & \\
\hline & & Kadın & 308 & 290,74 \\
\hline & & Erkek & 312 & 330,01 \\
\hline
\end{tabular}

Tablo 3'te ise Trakya Üniversitesi ve Afyon Kocatepe üniversitesi öğrencileri arasındaki farkları görebilmek için $p$ değeri kabul edilen yani cinsiyet ile aralarında ilişki olduğu ortaya konan eğilimler frekans ve ortalama değerleri ile verilmiştir. Trakya Üniversitesinde Eğilim B(Turizm bölümü öğrencileri mutlaka kendi işlerini kurmayı hedeflemelidir), Eğilim $D$ (Turizm bölümü öğrencileri mutlaka girişimci olmaya odaklanmalıdır) ve Eğilim J (Gerçekleri zorlayarak sezgiye, hislere ve hayallere dayalı hareket etmeyi tercih ederim )'de anlamlı bir ilişkinin varlığı anlaşılmıştır. Her üç eğilimde de erkeklerin ortalama değerlerinin daha yüksek olduğu görülmektedir. Afyon Kocatepe Üniversitesinde ise Eğilim D ve Eğilim E'de ayrışma görülmekte olup, Eğilim D (Turizm bölümü öğrencileri mutlaka girişimci olmaya odaklanmalıdır)'de kadınların Eğilim E (Turizm bölümü öğrencileri asla özel sektörde çalışmayı planlamamalıdır)'de ise erkeklerin daha yüksek eğilime sahip oldukları anlaşılmıştır. 
G. Yumuk Gunay

Tablo 3. Cinsiyet Açısından Trakya Üniversitesi ve Afyon Kocatepe Üniversitesi Karşılaştırması

\begin{tabular}{|l|l|l|l|l|l|l|l|l|c|}
\hline $\begin{array}{l}\text { TRAKYA } \\
\text { Cinsiyet }\end{array}$ & $\mathbf{P}$ & & & & $\begin{array}{c}\text { AFYON } \\
\text { Cinsiyet }\end{array}$ & $\mathbf{P}$ & & & \\
\hline Eğilim B & 0.031 & & Frekans & $\begin{array}{c}\text { Ortalama } \\
\text { Değer }\end{array}$ & Eğilim D & 0.010 & & Frekans & $\begin{array}{c}\text { Ortalama } \\
\text { Değer }\end{array}$ \\
\hline & & Kadın & 173 & 157,91 & & & Kadın & 132 & 156,54 \\
\hline & & Erkek & 163 & 179,74 & & & Erkek & 154 & 132,32 \\
\hline Eğilim D & 0.009 & & & & Ĕ̈ilim E & 0.036 & & & \\
\hline & & Kadın & 173 & 155,21 & & & Kadın & 132 & 133,04 \\
\hline & & Erkek & 162 & 181,65 & & & Erkek & 154 & 152,47 \\
\hline Eğilim J & 0.012 & & & & & & & & \\
\hline & & Kadın & 176 & 155,84 & & & & & \\
\hline & & Erkek & 159 & 181,46 & & & & & \\
\hline
\end{tabular}

\subsubsection{Yaş}

İncelenen diğer demografik faktör ise "yaş"'tır ve girişimcilik eğilimlerinin bireylerin içinde bulundukları yaş aralığına göre değişebileceği öngörülmektedir. Tüm öğrenciler dikkate alındığında yaş ile Eğilim C (Turizm bölümü öğrencileri asla kamu sektöründe çalışmayı planlamamalıdır) ve Eğilim $D$ (Turizm bölümü öğrencileri mutlaka girişimci olmaya odaklanmalıdır) arasında yaşa bağlı ilişkinin var olduğu gözlenmektedir. Araştırma sonuçlarının ilginç yanı Girişimcilik eğilimlerinin 18-19 yaşlarda daha fazla olduğunu ortaya koymasıdır. Aşağıdaki tabloda da görüldüğü gibi ilişki olduğu ortaya konan Eğilim $C$ $(P=0.003)^{\prime}$ de eğilimin en fazla 19 yaş grubunda olduğu gözlemlenirken Eğilim $D(P=0.016)$ 'de en fazla 18 yaş grubunun olduğu anlaşılmıştır. Bu durum öğrencilerin 18 yaşında iken "mutlaka girişimci olmaya odaklanılması" gerektiğini düşünürken 19 yaşında "asla kamu sektöründe çalışmayı planlamaması" gerektiği yönündedir. Bu durum 18-19 yaşlarının turizm öğrencileri için girişimcilik eğilimlerinin arttırılabileceği ve potansiyel becerilerinin ortaya çıkartılarak kendilerine olan güvenin arttırılabileceği bir yaş olduğunu ortaya koymaktadır.

Tablo 4. Yaş ve Girişimcilik Eğilimleri (Trakya Üniversitesi ve Afyon Kocatepe Üniversitesi)

\begin{tabular}{|c|c|c|c|c|}
\hline $\begin{array}{l}\text { GENEL } \\
\text { Yaş }\end{array}$ & $\mathbf{P}$ & & Frekans & $\begin{array}{l}\text { Ortalama } \\
\text { Değer }\end{array}$ \\
\hline \multirow[t]{10}{*}{ Eğilim C } & 0.003 & & & \\
\hline & & 17'den az & 1 & 105,50 \\
\hline & & 18 & 23 & 242,74 \\
\hline & & 19 & 80 & 381,40 \\
\hline & & 20 & 122 & 324,49 \\
\hline & & 21 & 146 & 295,22 \\
\hline & & 22 & 102 & 296,03 \\
\hline & & 23 & 76 & 302,80 \\
\hline & & 24 & 43 & 305,94 \\
\hline & & $24+$ & 27 & 268,74 \\
\hline \multirow[t]{10}{*}{ Eğilim D } & 0.016 & & & \\
\hline & & $17^{\prime}$ den az & 1 & 26,50 \\
\hline & & 18 & 23 & 388,41 \\
\hline & & 19 & 80 & 331,51 \\
\hline & & 20 & 122 & 329,61 \\
\hline & & 21 & 146 & 300,22 \\
\hline & & 22 & 102 & 290,63 \\
\hline & & 23 & 76 & 309,70 \\
\hline & & 24 & 42 & 311,74 \\
\hline & & $24+$ & 27 & 225,59 \\
\hline
\end{tabular}


Üniversiteler ayrı ayrı incelendiğinde ise (Tablo 5) durum daha net anlaşılmaktadır. Trakya üniversitesi öğrencilerinin yaşları ile Eğilim C (Turizm bölümü öğrencileri asla kamu sektöründe çalışmayı planlamamalıdır) arasındaki ilişkide 19 yaş grubu ağırlıkta iken Afyon Kocatepe öğrencilerinin yaşları ile Eğilim D (Turizm bölümü öğrencileri mutlaka girişimci olmaya odaklanmalıdır) arasındaki ilişkide 18 yaş grubu ağırlıktadır. Aslında yaş gruplarının birbirine yakın olması üniversiteler arası ciddi bir farklılığın olmadığını göstermektedir.

Tablo 5. Yaş Açısından Trakya Üniversitesi ve Afyon Kocatepe Üniversitesi Karşılaştırması

\begin{tabular}{|l|l|l|l|l|l|l|l|l|l|}
\hline $\begin{array}{l}\text { TRAKYA } \\
\text { Yaş }\end{array}$ & $\mathbf{P}$ & & & $\begin{array}{l}\text { AFYON } \\
\text { Yaş }\end{array}$ & $\mathbf{P}$ & & & \\
\hline Eğilim C & 0.001 & & Frekans & $\begin{array}{l}\text { Ortalama } \\
\text { Değer }\end{array}$ & Eğilim D & 0.012 & & Frekans & $\begin{array}{l}\text { Ortalama } \\
\text { Değer }\end{array}$ \\
\hline & & $\begin{array}{l}17^{\prime} \text { den } \\
\text { az }\end{array}$ & & & & & $\begin{array}{l}17 \text { 'den } \\
\text { az }\end{array}$ & 1 & 16,00 \\
\hline & 18 & 12 & 164,38 & & & 18 & 11 & 199,50 \\
\hline & & 19 & 63 & 193,09 & & & 19 & 18 & 144,03 \\
\hline & 20 & 70 & 174,88 & & & 20 & 52 & 157,06 \\
\hline & & 21 & 77 & 157,75 & & & 21 & 68 & 127,90 \\
\hline & 22 & 47 & 153,15 & & & 22 & 55 & 144,17 \\
\hline & 23 & 39 & 154,51 & & & 23 & 37 & 156,24 \\
\hline & 24 & 17 & 166,85 & & & 24 & 26 & 150,71 \\
\hline
\end{tabular}

\subsubsection{Sinıf}

Demografik faktörlerden "sınıf" incelenen üçüncü özelliktir. Sınıf faktörünün özellikle öğrencilerin eğitim süreleri içerisinde girişimciliğe olan bakışlarının değişip değişmediğinin ve bu değişimde alınan derslerin etkisinin olup olmadığının ortaya konulması açısından önemli görülmektedir. Öğrencilerin kaçıncı sınıfta oldukları göz önüne alındığında girişimcilik eğilimleri ile olan ilişkisinde Eğilim C (Turizm bölümü öğrencileri asla kamu sektöründe çalışmayı planlamamalıdır) ve Eğilim $D$ (Turizm bölümü öğrencileri mutlaka girişimci olmaya odaklanmalıdır)'nin p değeri \%5 anlamlıık düzeyinde kabul edilebilir çıkmıştır (Bkz Tablo 6). Eğilim C'de öğrencilerin öğrenimlerinin ilk yıllında yani 1. Sınıfta (2.dönem) en yüksek eğilime sahipken 2, ve 4 .sınıfa (4 ve 8.dönemlere) geldiklerinde eğilimlerinde düşme olmasıdır. 3.sınıf (6.dönem)'ta ufak bir yükselmenin yaşanması Trakya Üniversitesi öğrencilerinin o dönemde aldıkları girişimcilik dersinden kaynaklı olabileceği düşünülebilir.

Tablo 6. Sınıf ve Girişimcilik Eğilimleri Karşılaştırılması (Trakya Üniversitesi ve Afyon Kocatepe Üniversitesi)

\begin{tabular}{|l|l|l|l|l|}
\hline $\begin{array}{l}\text { GENEL } \\
\text { Sınıf }\end{array}$ & $\mathbf{P}$ & & Frekans & $\begin{array}{l}\text { Ortalama } \\
\text { Değer }\end{array}$ \\
\hline Eğilim C & 0.001 & & & \\
\hline & & 1(2.Dönem) & 155 & 339,02 \\
\hline & & 2(4.Dönem) & 239 & 282,14 \\
\hline & & 3(6.Dönem) & 117 & 290,28 \\
\hline & & 4(8.Dönem) & 74 & 249,49 \\
\hline & & 2+(4.Dön.) ve 4+(8.Dön.) & 3 & 254,17 \\
\hline Eğilim D & 0.000 & & & \\
\hline & & 1(2.Dönem) & 155 & 340,63 \\
\hline & & 2(4.Dönem) & 239 & 298,83 \\
\hline & & 3(6.Dönem) & 117 & 251,86 \\
\hline & & 4(8.Dönem) & 73 & 243,27 \\
\hline & & 2+ (4.Dön.) ve 4+(8.Dön.) & 3 & 377,83 \\
\hline
\end{tabular}


Tablo 7 incelendiğinde, Trakya Üniversitesi öğrencilerinin gerek Eğilim B (Turizm bölümü öğrencileri mutlaka kendi işlerini kurmayı hedeflemelidir), gerek Eğilim C (Turizm bölümü öğrencileri asla kamu sektöründe çalışmayı planlamamalıdır) ve gerekse Eğilim $D$ (Turizm bölümü öğrencileri mutlaka girişimci olmaya odaklanmalıdır)'de 1.sınıfta (2.dönem) yüksek bir eğilim oranı söz konusu olmasına rağmen, daha sonraki yıllarda düşmelerin olmasıdır. Yapılan araştırmada Trakya Üniversitesi öğrencilerinin eğitim sürelerinin 3. (6.dönem) sınıfında "girişimcilik" dersi aldıkları düşünüldüğünde Eğilim B ve Eğilim C'nin bu dönemdeki artışının eğitimden kaynaklı olumlu bir etki olarak düşünülmesi söz konusu olabilir. Afyon Kocatepe öğrencileri için ise Eğilim F (Bir işin fırsatlar sunması; emniyetli ve garantili olmasından daha önemlidir) de öğrenciler sınıfı arttıkça bunun eğilimlere de olumlu yansıdığını dolayısıyla son sınıfta en yüksek eğilime sahipken okullarını bitiremeyip artı olan öğrencilerin ise birden bu eğilimin düştüğü görülmektedir. Yine Afyon Kocatepe öğrencileri için Eğilim $N$ (Kariyerim için gerekli olsa dahi önceliklerimden vazgeçmem)'nin ilk yıl yüksek olmasına rağmen 2. Sınıfta (4.dönem) düşme olduğu ancak 3.ve 4. Sınıflarda (6.ve 8.dönemlerde) arttığı gözlemlenmiştir. Hatta bu artış mezun olamayan yani okulları uzayan öğrencilerde en yüksek seviyesine ulaşmıştır.

Tablo 7. Sınıf Açısından Trakya Üniversitesi ve Afyon Kocatepe Üniversitesi Karşılaştırılması

\begin{tabular}{|c|c|c|c|c|c|c|c|c|c|}
\hline $\begin{array}{l}\text { TRAKYA } \\
\text { SInıf }\end{array}$ & $\mathbf{P}$ & & & & $\begin{array}{l}\text { AFYON } \\
\text { Sinıf }\end{array}$ & $\mathbf{P}$ & & & \\
\hline \multirow[t]{6}{*}{ Eğilim B } & 0.004 & & Frekans & $\begin{array}{l}\text { Ortalama } \\
\text { Değer }\end{array}$ & Eğilim $F$ & 0.019 & & Frekans & $\begin{array}{l}\text { Ortalama } \\
\text { Değer }\end{array}$ \\
\hline & & 1(2.Dönem) & 139 & 190,45 & & & 1(2.Dönem) & 16 & 81,50 \\
\hline & & 2(4.Dönem) & 134 & 151,61 & & & 2(4.Dönem) & 105 & 123,86 \\
\hline & & 3(6.Dönem) & 36 & 156,06 & & & 3(6.Dönem) & 81 & 132,09 \\
\hline & & 4(8.Dönem) & 27 & 155,93 & & & 4(8.Dönem) & 47 & 142,18 \\
\hline & & $\begin{array}{l}\text { 2+(4.Dön.) ve } \\
4+(8 . \text { Dön.) }\end{array}$ & - & - & & & $\begin{array}{l}\text { 2+(4.Dön.) ve } \\
4+(8 . \text { Dön.) }\end{array}$ & 3 & 62,17 \\
\hline \multirow[t]{6}{*}{ Eğilim C } & 0.000 & & & & $\begin{array}{l}\text { Eğilim } \\
\mathrm{N}\end{array}$ & 0.050 & & & \\
\hline & & 1(2.Dönem) & 139 & 193,86 & & & 1(2.Dönem) & 16 & 139,94 \\
\hline & & 2(4.Dönem) & 134 & 150,07 & & & 2(4.Dönem) & 104 & 113,49 \\
\hline & & 3(6.Dönem) & 36 & 157,81 & & & 3(6.Dönem) & 81 & 131,59 \\
\hline & & 4(8.Dönem) & 27 & 143,65 & & & 4(8.Dönem) & 47 & 133,73 \\
\hline & & $\begin{array}{l}\text { 2+ (4.Dön.) ve } \\
4+(8 . \text { Dön.) }\end{array}$ & - & - & & & $\begin{array}{l}\text { 2+ (4.Dön.) ve } \\
4+(8 . \text { Dön.) }\end{array}$ & 3 & 213,33 \\
\hline \multirow[t]{6}{*}{ Eğilim D } & 0.000 & & & & & & & & \\
\hline & & 1(2.Dönem) & 139 & 189,65 & & & & & \\
\hline & & 2(4.Dönem) & 134 & 165,03 & & & & & \\
\hline & & 3(6.Dönem) & 36 & 113,63 & & & & & \\
\hline & & 4(8.Dönem) & 26 & 142,81 & & & & & \\
\hline & & $\begin{array}{l}2+\text { (4.Dön.) ve } \\
4+(8 . \text { Dön.) }\end{array}$ & & & & & & & \\
\hline
\end{tabular}

Burada önemle üzerinde durulması gereken nokta Afyon Kocatepe'de "girişimcilik" dersinin olmamasıdır. Dolayısıyla turizm öğrencilerinin eğilimlerindeki "girişimcilik dersinin etkisi" gözlemlenememiştir. Trakya Üniversitesinde "girişimcilik" dersi mevcuttur ve dersin öğrencilerin girişimcilik eğilimlerinde sadece o döneme ait kısa süreli bir etki yarattığı gözlemlenmektedir.

\subsubsection{Baba Mesleği}

Incelenen diğer bir demografik faktör ise "Baba Mesleği"dir. Gençlerin geleceklerini şekillendiren en önemli kişiler aileleridir. Özellikle "babanın mesleği" çocuğun gelecekte ne olmak istediği veya ne olmak istemediği konusunda en önemli bir kriterdir. Bu nedenle tüm öğrencilerin girişimcilik eğilimlerinde babalarının mesleğinin etkisi olup olmadığı aşağıdaki tabloda (Tablo 8) incelenmiştir. Baba mesleği "özel sektör" çalışanı olan öğrencilerin Eğilim C (Turizm bölümü öğrencileri asla kamu sektöründe çalışmayı planlamamalıdır) ile olan ilişki en yüksek iken, ikinci derecede baba mesleği "serbest meslek" olan 
öğrenciler kamu sektöründe çalışmayı düşünmemeleri gerektiğini savunmaktadırlar. Bu durum öğrencilerin babalarının izinden gitmeyi arzu ettiklerini göstermektedir. Baba mesleği "emekli" olan öğrencilerin ise Eğilim H (Sosyal yaşamı, iş yaşamını, eğlenceyi dengeli bir şekilde yaşayan bir kişiliğe sahip olmak isterim) ile ilişkisi en yüksek çıkmıştır. Eğilim H'ın yüksek çıktığı diğer baba meslekleri ise "özel sektör" ve "kamu çalışanı" dır. Bu ifade ile öğrenciler risk almayan, dengeli ve sakin bir hayat yaşamayı tercih eden aile üyesinin (babasının mesleğini) iş hayatının kendi kişiliği içinde uygun olduğunu düşünmektedir.

Tablo 8. Baba Mesleği ve Girişimcilik Eğilimleri (Trakya Üniversitesi ve Afyon Kocatepe Üniversitesi)

\begin{tabular}{|l|l|l|l|l|}
\hline $\begin{array}{l}\text { GENEL } \\
\text { Baba } \\
\text { Mesleği }\end{array}$ & P & Frekans & $\begin{array}{l}\text { Ortalama } \\
\text { Değer }\end{array}$ \\
\hline Eğilim C & 0.034 & & & \\
\hline & & Kamu çalışanı & 82 & 266,95 \\
\hline & & Özel sektör & 97 & 345,92 \\
\hline & & Serbest meslek & 111 & 307,01 \\
\hline & & Emekli & 221 & 297,81 \\
\hline & & Diğer & 96 & 304,05 \\
\hline Eğilim H & 0.001 & & & \\
\hline & & Kamu çalışanı & 82 & 293,29 \\
\hline & & Özel sektör & 97 & 285,87 \\
\hline & & Serbest meslek & 111 & 300,32 \\
\hline & & Emekli & 218 & 335,49 \\
\hline & & Diğer & 98 & 261,92 \\
\hline
\end{tabular}

Tablo 9'da Trakya Üniversitesi öğrencileri ile Afyon Kocatepe üniversitesi öğrencilerinin eğilimleri ile baba meslekleri arasındaki ilişki üniversite ayrımı yapılarak incelendiğinde Trakya üniversitesi öğrencilerinin baba meslekleri ile Eğilim L (İnandığım bir konu dahi olsa kural dışı davranmayı ve marjinal olmayı göze alamam) arasında tek bir ilişkiye rastlanmıştır. Burada da en fazla "serbest meslek" etkili olduğu gözlenmiştir.

Afyon Kocatepe öğrencilerinin sonuçlarında ise iki ilişkiye rastlanılmıştır (Eğilim C ve Eğilim H). Eğilim C ile öğrenciler baba mesleklerinde olduğu gibi "özel sektör", ve "serbest meslek" tercihleri ile kamuda çalışmayı düşünmediklerini ifade etmişlerdir. Eğilim $\mathrm{H}$ ile de sosyal yaşamda ve iş yaşamda dengeli bir kişiliğe sahip olduklarını ifade eden öğrencilerin babalarının "emekli" kesimi oluşturdukları görülmektedir.

Tablo 9. Baba Mesleği Açısından Trakya Üniversitesi ve Afyon Kocatepe Üniversitesi Karşılaştırılması

\begin{tabular}{|c|c|c|c|c|c|c|c|c|c|}
\hline $\begin{array}{l}\text { TRAKYA } \\
\text { Baba Mes. }\end{array}$ & $\mathbf{P}$ & & & & $\begin{array}{l}\text { AFYON } \\
\text { Baba Mes. }\end{array}$ & $\mathbf{P}$ & & & \\
\hline \multirow[t]{12}{*}{ Eğilim L } & 0.041 & & $\mathrm{~F}$ & O.D. & Eğilim C & 0.030 & & $\mathrm{~F}$ & O.D. \\
\hline & & Kamu çalışanı & 38 & 158,79 & & & Kamu çalışanı & 42 & 115,02 \\
\hline & & Özel sektör & 52 & 142,02 & & & Özel sektör & 46 & 167,21 \\
\hline & & Serbest meslek & 64 & 186,45 & & & Serbest meslek & 46 & 142,45 \\
\hline & & Emekli & 122 & 156,65 & & & Emekli & 99 & 135,49 \\
\hline & & Diğer & 52 & 182,56 & & & Diğer & 46 & 142,85 \\
\hline & & & & & Eğilim H & 0.003 & & & \\
\hline & & & & & & & Kamu çalışanı & 42 & 132,06 \\
\hline & & & & & & & Özel sektör & 45 & 119,44 \\
\hline & & & & & & & Serbest meslek & 46 & 132,68 \\
\hline & & & & & & & Emekli & 98 & 161,42 \\
\hline & & & & & & & & 46 & 23,01 \\
\hline
\end{tabular}




\subsubsection{Mesleki Hedef}

Gerek Trakya Üniversitesi gerekse Afyon Kocatepe Üniversitesi öğrencilerinin gelecekte yapmak istedikleri meslek ile girişimcilik eğilimi arasındaki ilişki incelenmiş ve aşağıdaki tabloda bu ilişkiye ait bilgiler yer verilmiştir. Tablo 10'da Eğilim B, Eğilim C, Eğilim E ve Eğilim H ile girişimcilik eğilimi arasında ilişkinin varlığı gözlemlenmiştir. Eğilim B(Turizm bölümü öğrencileri mutlaka kendi işlerini kurmayı hedeflemelidir) fikrini savunanlar ile Eğilim C (Turizm bölümü öğrencileri asla kamu sektöründe çalışmayı planlamamalıdır) düşüncesine sahip öğrenciler doğal olarak "kendi işini kurma” arzusunda olanlardır. Eğilim E (Turizm bölümü öğrencileri asla özel sektörde çalışmayı planlamamalıdır)'nin en yüksek ortalama değerine sahip olanlar baba mesleğini icra etmek isteyen ve kendi işini kurma arzusunda olan öğrencilerdir. Eğilim $\mathrm{H}$ (Sosyal yaşamı, iş yaşamını, eğlenceyi dengeli bir şekilde yaşayan bir kişiliğe sahip olmak isterim)'nın en yüksek olduğu mesleki hedefler ise özel sektörde çalışmak isteyen öğrencilerdir.

Tablo 10. Mesleki Hedef ve Girişimcilik Eğilimleri (Trakya Üniversitesi ve Afyon Kocatepe Üniversitesi)

\begin{tabular}{|c|c|c|c|c|}
\hline $\begin{array}{l}\text { GENEL } \\
\text { Mesleki } \\
\text { Hedef }\end{array}$ & $\mathbf{P}$ & & Frekans & $\begin{array}{l}\text { Ortalama } \\
\text { Değer }\end{array}$ \\
\hline \multirow[t]{6}{*}{ Eğilim B } & 0.048 & & & \\
\hline & & Devlet Memurluğu & 178 & 289,45 \\
\hline & & Baba Mesleğini Sürdürme & 10 & 324,45 \\
\hline & & Özel sektör & 194 & 291,93 \\
\hline & & Kendi işini Kurma & 189 & 336,57 \\
\hline & & Diğer & 39 & 290,79 \\
\hline \multirow[t]{6}{*}{ Eğilim C } & 0.000 & & & \\
\hline & & Devlet Memurluğu & 178 & 249,82 \\
\hline & & Baba Mesleğini Sürdürme & 10 & 203,60 \\
\hline & & Özel sektör & 194 & 321,74 \\
\hline & & Kendi işini Kurma & 189 & 343,00 \\
\hline & & Diğer & 39 & 323,23 \\
\hline \multirow[t]{6}{*}{ Ĕğilim E } & 0.022 & & & \\
\hline & & Devlet Memurluğu & 177 & 319,16 \\
\hline & & Baba Mesleğini Sürdürme & 9 & 339,22 \\
\hline & & Özel sektör & 196 & 274,07 \\
\hline & & Kendi işini Kurma & 190 & 321,69 \\
\hline & & Diğer & 40 & 329,86 \\
\hline \multirow[t]{6}{*}{ Eğilim H } & 0.018 & & & \\
\hline & & Devlet Memurluğu & 176 & 298,64 \\
\hline & & Baba Mesleğini Sürdürme & 10 & 235,40 \\
\hline & & Özel sektör & 195 & 321,18 \\
\hline & & Kendi işini Kurma & 188 & 312,09 \\
\hline & & Diğer & 40 & 238,21 \\
\hline
\end{tabular}

Aşağıda Tablo 11'de üniversiteler ayrı ayrı incelenmiş ve Trakya Üniversitesi öğrencilerinin mesleki hedeflerinde yer alan meslek grubu ile Eğilim C arasında ilişki olduğu gözlemlenmiştir. Kendi işini kurmak hedefinde olan öğrencilerin Eğilim C (Turizm bölümü öğrencileri asla kamu sektöründe çalışmayı planlamamalıdır) eğilimine sahip öğrenciler olduğu anlaşılmaktadır. 
Turizm Bölümü Öğrencilerinin Girişimcilik Eğilimlerini Etkileyen Demografik Faktörler: îki Devlet Üniversitesi Karşılaştırması

Tablo 11. Mesleki Hedef Açısından Trakya Üniversitesi ve Afyon Kocatepe Üniversitesi Karşılaştırılması

\begin{tabular}{|c|c|c|c|c|c|c|c|c|c|}
\hline $\begin{array}{l}\text { TRAKYA } \\
\text { M. H. }\end{array}$ & $\mathbf{P}$ & & & & $\begin{array}{l}\text { AFYON } \\
\text { M. H. }\end{array}$ & $\mathbf{P}$ & & & \\
\hline Eğilim C & 0.001 & & $\mathrm{~F}$ & O.D. & Eğilim C & 0.003 & & $\mathrm{~F}$ & O.D. \\
\hline & & Devlet Memurluğu & 69 & 127,87 & & & Devlet Memurluğu & 109 & 122,72 \\
\hline & & $\begin{array}{l}\text { Baba Mesleğini } \\
\text { Sürd. }\end{array}$ & 4 & 134,38 & & & $\begin{array}{l}\text { Baba Mesleğini } \\
\text { Sürd. }\end{array}$ & 6 & 84,42 \\
\hline & & Özel sektör & 121 & 164,55 & & & Özel sektör & 73 & 157,20 \\
\hline & & Kendi işini Kurma & 116 & 184,86 & & & Kendi işini kurma & 73 & 156,82 \\
\hline & & Diğer & 17 & 171,35 & & & Diğer & 22 & 153,59 \\
\hline & & & & & Eğilim H & 0.043 & & & \\
\hline & & & & & & & Devlet Memurluğu & 108 & 139,61 \\
\hline & & & & & & & $\begin{array}{l}\text { Baba Mesleğini } \\
\text { Sürd. }\end{array}$ & 6 & 101,17 \\
\hline & & & & & & & Özel sektör & 73 & 139,05 \\
\hline & & & & & & & Kendi işini Kurma & 72 & 157,94 \\
\hline & & & & & & & Diğer & 22 & 109,68 \\
\hline
\end{tabular}

Afyon Kocatepe üniversitesi öğrencilerinin mesleki hedefleri ile eğilimleri karşılaştırıldığında Eğilim $C$ ve Eğilim $\mathrm{H}$ arasında kabul edilebilir $(P=0.003$ ve $P=0.043$ ) bir ilişki gözlemlenmiştir. Eğilim $C$ (Turizm bölümü öğrencileri asla kamu sektöründe çalışmayı planlamamalıdır)'de özel sektörde çalışmak isteyenler ile kendi işini kurma düşüncesinde olan öğrenciler aynı frekans ve çok yakın ortalama değerler ile ilk sıralarda yer almaktadırlar. Eğilim H (Sosyal yaşamı, iş yaşamını, eğlenceyi dengeli bir şekilde yaşayan bir kişiliğe sahip olmak isterim)'da ise öğrenciler genel sonuçların aksine (Tablo 10'a bakınız) dengeli yaşamı kendi işlerini kurduklarında gerçekleştirebileceklerini düşünmektedir. Bu durumda öğrencilerin kendi işlerini kurduklarında daha özgür, daha iyi çalışma koşullarına ve dengeli bir iş-aile yaşamına sahip olacaklarına inandıkları görülmektedir.

\section{Sonuç ve Öneriler}

Birçok ülke için girişimcilik önemlidir. Çünkü girişimciler sayesinde sermaye tabana yayılmakta, istihdam yaratılmakta, yaratılan dinamizm ile ekonomiler güçlü kılınmaktadır. Bu bağlamda girişimciliğin gelişiminde, üzerinde durulması gereken bir konuda girişimciler, özellikle genç girişimcilerdir. Girişimciliği etkileyen yaratıcılık ve inovasyonun yanında en önemli faktörlerden biride demografik özelliklerdir (Stangler ve Spulber, 2013:1). Coulter (2003:26) girişimci bireylerin demografik özelliklerin başında cinsiyeti, yaşı, eğitimi, iş tecrübesini ve girişimci bir aileden gelmesini saymaktadır.

Üniversite öğrencilerinin girişimcilik eğilimlerini araştıran birçok çalışmada (Kahya ve İmamoğlu, 2013:9; Şeşen ve Basım, 2012:25, Dündar ve Ağca, 2007:140) mutlaka ilk önce cinsiyetten kaynaklı bir farklılık test edilmeye çalışılmıştır. Çalışmada da demografik faktörler içerisinde ilk olarak "cinsiyet" ele alınmıştır. Sonuçlar kadınların erkeklere göre daha fazla kendi işlerini kurmak için gerekli fırsatları yaratma yeteneğine sahip olduklarını göstermektedir. Ancak işin emniyetli/garantili olmasından ziyade fırsatlar sunması, yüksek maddi kazanç sağlaması, gerçeklerin üzerine çıkarak sezgilerin ve hayallerin peşinden gitme arzusunun erkeklerde daha ağır bastığı çalışmanın diğer önemli bir sonucudur. Çalışmanın bu sonuçları, Wang ve Wong (2004:170), Cansız (2007:89-90), Akın ve Zor (2009: 123), İşcan ve Kaygın (2011:456) tarafından gerçekleştirilen çalışmaları destekler niteliktedir. "Yaş" faktörü incelendiğinde ise 18-19 ve 20 yaşlarındaki gençlerin mutlaka girişimci olma ve kamu sektöründe çalışmak istememe gibi bir eğilimlerinin olduğu, daha sonraki yaşlarda bunun değiştiği gözlenmektedir. Oysa ki Karasakal ve Aksu (2014:115) gerçekleştirdikleri çalışmada 20 yaş üstü sosyal program öğrencilerindeki girişimcilik eğilimlerinin daha yüksek olduğunu vurgulamaktadır. Çalışma sonuçları ile literatür arasında yaşa bağıı farklııklar söz konusu olmakla birlikte, çalışmamızdaki sonuçlar öğrencilerin ilerleyen yaşlarda (20'den sonra) girişimci olma eğilimlerindeki düşmenin sebebinin iş kurma fikrinin riskli görülerek, kendileri için garantili gördükleri işleri 
(Kamuda çalışmak gibi) tercih etmelerinden kaynaklanabilmektedir. Stangler (2013:1) gerçekleştirdiği çalışmasında da bireylerin yaşları ilerledikçe risk alma toleranslarının düşük, fırsat maliyetlerinin yüksek olduğunu dolayısıyla kendi işlerini gerçekleştirme (girişimcilik) eğilimlerinin düştüğünü ifade etmektedir. "Sınıf" karşılaştırmalarında öğrencilerin girişimcilik eğilimlerinin ilk yıl yüksek olmasına rağmen daha sonraki yıllarda düşüşe geçtiği görülmektedir. Aslında bunun sebebini Wang ve Wong (2004: 166) beşeri sermayenin fırsat maliyetine ve öğrencilerin mezun olduklarında (eğitim düzeyleri artmış olacak) büyük firmalarda iş bulacaklarına, inanmalarına bağlamaktadır. Ancak mezun olamayıp (+) konumunda olan öğrencilerin eğilimlerinde artış olması, iş hayatında çalışmaya başlayan öğrencilerin turizm sektöründeki zor çalışma koşulları nedeniyle tekrar kendi işlerini kurma hayallerini kurduklarını göstermektedir. Baba mesleği kategorisinde öğrencilerin babalarının mesleğinden etkilendikleri dolayısıyla babası özel sektörde çalışanların ve kendi işini yapanların (belki de aile işini devam ettirmek adına) kesinlikle kamuyu düşünmedikleri görülmektedir. Girişimciliği etkileyen en önemli özelliklerden biri olan aile faktöründe kendi işine sahip babaların güçlü bir tetikleyici rol üstlendikleri Hisrich ve Peters (1995:55-58), Kutaniş vd. (2006:390-391), Akın ve Zor (2009:125 ve 134), Çelik, İnce ve Bozyiğit (2014:122) tarafından da ifade edilmektedir. Mesleki hedef kategorisinde yine kendi işini kurma hedefindeki öğrencilerin doğal olarak kendi işlerini kurma arzusunda olmaları (Eğilim B), kamuda çalışmayı planlamadıkları (Eğilim C) gözlenmektedir. Ayrıca özel sektörde çalışmayı planlamayan (Eğilim E) öğrencilerin hedefinin baba mesleğini devam ettirmek olduğu ifade edilmektedir. Sosyal yaşamı iş yaşamını ve eğlenceyi dengede tutma (Eğilim H)'nın yolunun mesleki hedeflerde ilk sırada olmasa bile ikinci sırada kendi işini kurmaktan vaz geçtiği görülmektedir.

Afyon Kocatepe ve Trakya üniversitesi turizm bölümü öğrencilerinin demografik özelliklerine göre girişimcilik eğilimleri arasında benzerlik ve farklılıklar söz konusudur. Cinsiyet açısından Turizm öğrencilerinin mutlaka girişimciliğe odaklanmaları gerektiğini düşünenler Trakya Üniversitesinde "Erkekler" çoğunlukta iken Afyon Kocatepe Üniversitesinde "Kadınlar" ağırlıktadır. Bu iki üniversite arasında cinsiyet açısından önemli bir farklılığa işaret etmektedir. Yaş açısından üniversiteler arasında farklılığı ortaya koymak amacıyla aynı eğilime ait ilişki bulunmamıştır. Ancak bir birleri ile paralel yargılar içeren "kamuda çalışmayı düşünmemek" ve "girişimciliğe odaklanmak" konusundaki ifadeler birbirlerine yakın (18-19 ve 20) yaşlarda birbirlerine benzerlik göstermektedir. Sınıf karşılaşmalarında üniversiteler arasında aynı eğilime ait ilişki söz konusu olmamıştır. Ancak farklı eğilimlerin karşılaştırılmasına bakıldığında Trakya üniversitesin (Eğilim B, Eğilim C ve Eğilim D) 1. Sınıf öğrencisinin eğilimi yüksek olup daha sonraki sınıflarda düşme eğilimi göstermiştir. Trakya üniversitesi öğrencilerinin 3. Sınıfta girişimcilik dersi almalarının sadece o dönem için "turizm öğrencilerinin mutlaka kendi işlerini kurmayı hedeflemelidir" eğilimini yükselttiğini ancak daha sonra tekrar düşüşe geçtiği görülmektedir. Aslında bu durum eğitimin kısmen de olsa etkisinin var olduğunu göstermektedir. Afyon Kocatepe üniversitesinde Eğilim F ve Eğilim N'nin ortalama değerleri 1. Sınıfta düşük olmasına rağmen diğer sınıflarda artış göstermektedir. Sınıf karşılaştırmalarında ortaya konmak istenen özellikle "girişimcilik" dersinin eğilimlerde bir farkııık yaratıp yaratmadığını ortaya koymak amacı taşımaktaydı. Ancak Afyon Kocatepe Üniversitesinde "girişimcilik" dersinin olmaması bu karşılaştırmayı yapma imkanımızı ortadan kaldırmıştır. Ancak Trakya Üniversitesi için 1. sınıfta yüksek olan eğiliminin üniversite de geçen sürenin artması ile daha sonraki sınıflarda (sadece 3 sınıf-6. dönemde artmış) azaldığını göstermektedir. Bu sonuç Wang ve Wong (2004:166) 'un çalışmasın da söyle açıklanmaktadır. Öğrencilerin yükseköğretim düzeyi arttıkça yani mezun olmaya yaklaştıkça büyük firmalardaki kariyer fırsatlarına sahip olabileceklerini düşünmekte ve bu durum girişimcilik eğilimlerine olumsuz yansımaktadır. Üniversiteler arası karşılaştırmada baba mesleğinin eğilimler arasındaki ilişkisi incelendiğinde, burada da farklı eğilimler (Trakya Üniversitesi için Eğilim L, Afyon Kocatepe Üniversitesi için Eğilim C ve Eğilim H) ile farklı baba meslekleri (Trakya Üniversitesi için Serbest Meslek, Afyon Kocatepe Üniversitesi için özel sektör ve Emekli) arasında ilişki olduğu gözlemlenmiştir. Son olarak iki üniversite karşılaştırmasında Mesleki Hedef'ler ile Eğilim C arasında ilişkiye rastlanmıştır. Bu ilişkide her iki üniversite sonuçları birbirine benzerlik göstermektedir. Sonuçlarda "kendi işini kurma" hedefi ön plana çıkmakla birlikte Afyon Kocatepe üniversitesinde "özel sektör" hedefi de ağırlıktadır.

Sonuç olarak; üniversiteler arasında farklılıklar ve benzerlikler olmakla birlikte çalışmanın en önemli bulgularından birisi girişimcilik için çok önemli olduğu düşünülen girişimcilik eğitimi ile ilgili bulgulardır. 
Girişimcilik eğitiminin girişimciliği olumlu katkısı olacağı birçok çalışmayla Mayer vd., 2000; Souitaris vd., 2007:585 ; Bozkurt, Aslan ve Göral, 2011:831; Martin vd., 2013:214; Zhou vd., 2014: 3) desteklenmekle birlikte bu çalışmada (Trakya Üniversitesi için) kısa sürelide olsa geçmiş çalışmaları desteklemektedir. Ancak uzun süreli bir etkinin olması ve bunun girişimcilik eylemi ile sonuçlanabilmesi için bir takım ilave desteklere (konuk konuşmacı, danışmanlık projeleri ve mentorluk programları vb. (Kassean vd. 2015:694) intiyaç olduğu gözlenmektedir. Bu bağlamda dersin içeriğinin, işleniş şeklinin ve belki de ders programı içerisindeki yerinin irdelenmesi gerektiğini düşündürmektedir. Afyon üniversitesinde ki öğrencilerin hiç girişimcilik dersi almamaları ise girişimciliğin önemi ve Trakya üniversitesi öğrencilerinde yarattığı etki göz önüne alındığında, en azında seçmeli ders olarak müfredata eklenmesinin yararlı olacağı yönündedir. Ayrıca üniversite dışında verilen (KOSGEB, kalkınma ajansı, girişimcilik merkezleri ve sanayi ticaret odaları aracılığı ile verilen) girişimcilik eğitimlerinin de gün geçtikçe artması üniversitelerinde bu konuyu ciddiye almaları gerektiğini göstermektedir.

\section{Kaynaklar}

Adaman, F., \& Devine, P. (2002). A reconsideration of the theory of entrepreneurship: A participatory approach. Review of Political Economy, 14(3), 329-355.

Akın, A., \& Zor, i. (2009). İşletmecilik eğitiminin bireyin girişimci niteliklerinin geliştirilmesine etkileri. İş, Güç Endüstri ilişkileri ve Insan Kaynakları Dergisi, 11 (1) , . 113-138.

Audretsch, D. B. (2003). Entrepreneurship: A survey of the literature, prepared for the European Commission. Enterprise Papers (14) http://ec.europa.eu/enterprise/ newsroom/cf/getdocument.cfm?doc_id=1837, (Erişim Tarihi, 15 Nisan 2015).

Aytaç, Ö. (2006). Girişimcilik: Sosyo-kültürel bir perspektif. Dumlupınar Üniversitesi Sosyal Bilimler Dergisi, Sayı:15.

Balaban, Ö., \& Özdemir, Y. (2008). Girişimcilik eğitiminin girişimcilik eğilimi üzerindeki etkisi: Sakarya Üniversitesi iïBF örneği. Girişimcilik ve Kalkınma Dergisi, 3(2), 133-147.

Bozkurt, Ö., Aslan, Z., \& Göral, M. (2011). Yükseköğretimde verilen girişimcilik eğitiminin öğrencilerin girişimcilik eğilimine etkisi: Teknik program ve sosyal program karşılaştırması bir araştırma. Uluslararası Yükseköğretim Kongresi: Yeni Yönelişler ve Sorunlar (UYK-2011), 27-29 Mayıs, İstanbul; 2. Cilt / Bölüm VIII /, 822-833.

Bozkurt, Ö., \& Erdurur, K. (2013). Girişimci kişilik özelliklerinin girişimcilik eğilimindeki etkisi: Potansiyel girişimciler üzerinde bir araştırma. Girişimcilik ve Kalkınma Dergisi, 8 (2), 57-78.

Brandstätter, H. (1997). Becoming an entrepreneur-a question of personality structure? Journal of Economic Psychology, 18, 157-177.

Bygrave, W.D., \& Hofer, C.W. (1991). Theorizing about entrepreneurship. (16)2, Publisher: Blackwell Publishing Limited, 13-22.

Cansız, E. (2007). Üniversite öğrencilerinin girişimcilik özelliklerinin belirlenmesi: Süleyman Demirel Üniversitesi öğrencileri üzerine bir çalışma. Süleyman Demirel Üniversitesi, Sosyal Bilimler Enstitüsü, Yayınlanmamış Yüksek Lisans Tezi,.

Chen Y.F., \& Lai, M.C. (2010). Factors influencing the entrepreneurial attitude of Taiwanese tertiary-level, business students. Social Behavior And Personality, 38(1), 1-12.

Chicken, J. C., (2002). Yönetim ve girişimcilik. Epsilon Yayıncılık, İstanbul.

Coulter, M. (2001). Entrepreneurship in action. Small business 2000. NewJersey: Prentice- Hall.

Coulter, M. (2003). Entrepreneurship in action. Second ed. New Jersey: Prentice Hall.

Çelik, A., İnce, M., \& Bozyiğit, S. (2014). Üniversite öğrencilerinin girişimcilik niyetlerini etkileyen ailesel faktörleri belirlemeye yönelik bir çalışma. Niğde Üniversitesi iktisadi Idari Bilimler Fakültesi Dergisi, 7(3), 113-124.

Deakins, D. ( 1999). Entrepreneurship and small firms. England: McGraw-Hill Publishing Company.

Dündar, S., \& Ağca, V. (2007). Afyon Kocatepe Üniversitesi lisans öğrencilerinin girişimcilik özelliklerinin incelenmesine ilişkin ampirik bir çalışma. H.Ü.iktisadi Idari Bilimler Fakültesi Dergisi, 25(1), 121-142.

Entrialgo, E., \& Iglesias, V. (2016). The moderating role of entrepreneurship education on the antecedents of entrepreneurial Intention. Int Entrep Manag J, Springer Science+Business Media New York 2016, DOI $10.1007 / \mathrm{s} 11365-016-0389-4,1-24$. 
Erdoğan, B.Z. (2008). Girişimcilik ve KOBi’ler teori ve uygulama. Ekin Basım Yayın Dağıtım, Bursa.

Girginer, N., \& Uçkan, N. (2004). İşletmecilik eğitimi alan lisans öğrencilerinin girişimciliğe bakış açıları: Eskişehir Osmangazi Üniversitesi i̇.i.B.F İşletme Bölümü öğrencilerine yönelik bir uygulama. III. Ulusal Bilgi, Ekonomi ve Yönetim Kongresi, 783-795.

Güreşçi, E. (2014). Girişimcilik eğilimi üzerine bir araştırma: İspir Hamza Polat MYO örneği. Girişimcilik ve Kalkınma Dergisi, 9(1), 23-38.

Gürol, Y., \& Atsan, N. (2006). Entrepreneurial characteristics amongst university students some insights for entrepreneurship education and training in Turkey. Education + Training, 48 (1), 25-38.

Hebert, F. R., \& Link, A.N. (2006). The entrepreneur as innovator. Journal of Technology Transfer, Springer Science.

Hisrich, R.D., \& Peters, M.P. (1995). Entrepreneurship: Starting, developing, and managing a new enterprise. (3. ed.), Chicago: Irwin.

Hisrich, R. D., \& Peters, M. P. (2002). Entrepreneursship. Mc Graw-Hill Irwin, USA.

İşcan, Ö.F., \& Kaygın, E. (2011). Üniversite öğrencilerinin girişimcilik eğilimlerini belirlemeye yönelik bir araştırma. Atatürk Üniversitesi Sosyal Bilimler Enstitüsü Dergisi, 15(2):443-462.

Kahya, C., \& İmamoğlu, i.K. (2013). Sosyo-demografik özellikler ve girişimcilik ilişkisinin yerel kalkınma bağlamında değerlendirilmesi (Bayburt ili örneği). Akademik Bakış Dergisi, Sayı: 38 (Eylül - Ekim), 1-14.

Karasakal Kaleli, N., \& Aksu, B. (2014). Meslek yüksekokulu teknik ve sosyal program öğrencilerinin sosyal karşılaştırılması sonucu girişimci kişilik eğilimlerini ortaya koymaya yönelik bir alan araştırması. Organizasyon ve Yönetim Bilimleri Dergisi, 6(2), 102-116.

Kao, J. (1989). Entrepreneurship, creativity, and organization: Text, cases, and readings. Prentice Hall.

Karimi, S., Biemans, H.J.A., Lans, T., Chizari, M., \& Mulder, M. (2016). The impact of entrepreneurship education: A study of Iranian students' entrepreneurial intentions and opportunity identification. Journal of Small Business Management, 54(1), 187-209.

Kassean, H., Vanevenhoven, J., Liguori, E., \& Winkel, D.E. (2015). Entrepreneurship education: A need for reflection, real-world experience and action. International Journal of Entrepreneurial Behavior \& Research, 21 (5), 690 708.

Kayış, A. (2010). Girişimcilik ve iç girişimciliğin önündeki engeller: Yazılım sektöründe bir uygulama. Gebze Yüksek Teknoloji Enstitüsü Sosyal Bilimler Enstitüsü, Yüksek Lisans Tezi, Gebze.

Koh, C.H. (1996). Testing hypotheses of entrepreneurial characteristics: A study of Hong Kong MBA students. Journal of Managerial Psychology, 11 (3), 12-25.

Korkmaz, S. (2000), Girişimcilik ve üniversite öğrencilerinin girişimcilik özelliklerinin belirlenmesine yönelik bir çalışma. H.Ü. Iktisadi ve Idari Bilimler Fakültesi Dergisi, 18(1), 163-169.

Kutaniş, R.Ö., Bayraktaroğlu, S., \& Bozkurt, Ö. (2006). Girişimcilik eğilimi ve tecrübesinde kişilik özellikleri önemli mi? 14. Ulusal Yönetim ve Organizasyon Kongresi, Erzurum, 389-395.

Martin, B., McNally, J.J., \& Michael, K. (2013). Examining the formation of human capital in entrepreneurship: A metaanalysis of entrepreneurship education outcomes. Journal of Business Venturing, 28 (2), 211-224.

Mayer, J.D., Salovey, P., \& Caruso, D.R. (2000). Models of emotional intelligence. In R.J.Sternberg (ed.), Handbook of Intelligence (2nd ed.), 396-420. Cambridge University Press: New York. http://www.unh.edu/emotional_ intelligence/El\%20Assets/ Reprints...El\%20Proper/ El2000ModelsSternberg.pdf, (Erişim Tarihi, 27 Ağustos 2015).

McDermond, J.M. (2012). Who's an entrepreneur now? A graphical breakdown shows how founder demographics have changed across the U.S. since 1996. http://www.inc.com john-mcdermott/entrepreneur-demographicswhos-an-entrepreneur-now.html (Erişim Tarihi, 26 Ocak 2016).

Minniti, M., \& Bygrave, W. (2000). The social dynamics of entrepreneurship. Entrepreneurship theory and practice, Spring.

Mueller, S.L., \& Thomas, A.S. (2000). Culture and entrepreneurial potential: A nine country study of locus of control and innovativeness. Journal of Business Venturing, 16, 51-75.

Müftüoğlu, T., \& Durukan, T. (2004). Girişimcilik ve KOBi'ler. (1. Basım), Ankara: Gazi Kitabevi.

Özdemir, Y., \& Mazgal, S. (2012). Bir kariyer tercihi olarak girişimcilikte dışsal faktörlerin etkisi: Sakarya örneği. Girişimcilik ve Kalkınma Dergisi, (7:1), 87-102.

Philipsen, K. (1998). Entrepreneurship as organizing. DRUID Summer Conference, Bornholm. 
Sciascia, S. , \& De Vita, R. (2004). The development of enrrepreneurship research. Liuc Papers, n. 146, Serie Economia Aziendale 19.

Souitaris, V., Zerbinati, S., \& Al-Laham, A. (2007). Do entrepreneurship programmes raise entrepreneurial intention of science and engineering students? The effect of learning, inspiration and resources. Journal of Business Venturing, 22, 566-591.

Stangler, D., \& Spulber, D. (2013). Demographics and entrepreneurship. IIIJ Innovation and Communication, Menlo Park, USA, pp:1-27.

Şeşen, H., \& Basım, N. (2012). Demografik faktörler ve kişiliğin girişimcilik niyetine etkisi: Spor bilimleri alanında öğrenim gören üniversite öğrencileri üzerine bir araştırma. EGE Akademik Bakış, Cilt: 12, Özel Sayı, 1-28.

Türker, D., \& Sönmez Selçuk, S. (2009). Which factors affect entrepreneurial intention of university students? Journal of European Industrial Training, 33(2), 142-159.

Wang, K. C., \& Wong, P.K. (2004). Entrepreneurial interest of university students in Singapore. Technovation, 24(2), 163-72.

Yumuk Günay, G. (2013). Turizm bölümü öğrencilerinin girişimcilik eğitimlerinin girişimcilik eğilimine etkisi. Trakya Üniversitesi iiBF Uluslararası E-dergi, 2 (2), 96-120.

Zhou, H., \& Estrada, I., \& Bojica, A. (2014). The role of emotional intelligence on entrepreneurs' perception of success. http://papers.ssrn.com/sol3/papers.cfm?abstract_id=2436333, (Erişim Tarihi, 3 Eylül 2015). 